\title{
Screening of Selected Ethno-Medicinal Plants for Anti-Cancer Activity
}

\author{
Utpal Dongre $^{1}$, Tanay Meshram¹, Swarali Dighe', Ketaki Narnawre', Bhuvaneshwari Mehere', \\ Subhash R. Somkuwar,"*
}

${ }^{1}$ Department of Biochemistry and Biotechnology, Dr. Ambedkar College, Deekshabhoomi, Nagpur (MS), India

${ }^{2}$ Department of Botany, Dr. Ambedkar College, Deekshabhoomi, Nagpur (MS), India

Received March 24, 2020; Revised May 19, 2020; Accepted May 26, 2020

\section{Cite This Paper in the following Citation Styles}

(a): [1] Utpal Dongre, Tanay Meshram, Swarali Dighe, Ketaki Narnawre, Bhuvaneshwari Mehere, Subhash R. Somkuwar, "Screening of Selected Ethno-Medicinal Plants for Anti-Cancer Activity," Advances in Zoology and Botany, Vol. 8, No. 5, pp. 447 - 452, 2020. DOI: 10.13189/azb.2020.080509.

(b): Utpal Dongre, Tanay Meshram, Swarali Dighe, Ketaki Narnawre, Bhuvaneshwari Mehere, Subhash R. Somkuwar (2020). Screening of Selected Ethno-Medicinal Plants for Anti-Cancer Activity. Advances in Zoology and Botany, 8(5), 447 - 452. DOI: 10.13189/azb.2020.080509.

Copyright $\odot 2020$ by authors, all rights reserved. Authors agree that this article remains permanently open access under the terms of the Creative Commons Attribution License 4.0 International License

\begin{abstract}
Cancer is an epidemic worldwide. As per the report of the National Centre for Health Statistics in 2019, approximately 606,880 patients were died due to cancer and $1,762,450$ new cases were detected. To overcome this scenario, worldwide research is going on to combat this disease. Among these, treatment of cancer through plant phytochemical has attended much prominence in the last few decades. Phytochemicals are produced by plants for their defense mechanism. However, these can also be used to treat many deadly diseases, among them cancer is most common. In the present study, we selected three Ethno-medicinal plants namely Careya arborea (leaf), Ficus religiosa (leaf) and Amorphophallus campanulatus (tuber) to evaluate their efficacy against A549 human lung cancer cells. MTT assay is widely used to assess cell viability. Human lung adenocarcinoma cell lines were purchased from NCCS, Pune and maintained in the laboratory under all standard conditions. Cells were grown, using ready to use media containing 4.5 grams of glucose, L-glutamine and sodium pyruvate. Growth factors were made available to the cells through the fetal bovine serum. We treated the cells with different concentrations of methanol and distilled water extracts of the selected plants and investigate the cell viability using a statistical test. We found varied significant differences between control cells and the cells treated with plant extracts.
\end{abstract}

Keywords Ethno-Medicinal Plants, A459 Lung Cancer, Phytochemicals, Cancer

\section{Introduction}

Lung cancer is most common in men and the third most common cancer in women. In low and middle income countries $50 \%$ deaths are due to lung cancer [1]. Today, despite worldwide cancer eradication and awareness programmes, cancer established itself a killer disease around the globe.

When normal cells lose their regulatory mechanisms and halt apoptosis leads to abnormal growth of cells and tissue, called as cancer. These mechanisms make cell resistant to chemotherapeutic drugs [2]. Indeed, it took more than five decades to establish a systematic drug discovery on cancer what we have today. However, chemotherapeutics as a treatment in cancer do not devoid their intrinsic problems. Use of these agents for cancer treatment often creates more secondary complications in patient. For example, use of a chemotherapeutic agent, called as 5-fluorouracil is known to cause myelotoxicity, cardiotoxicity and often thought to act as a vasospastic agent in few documented cases [3, 4]. Drug doxorubicin has been reported to cause renal toxicity, cardiac toxicity and myelotoxicity. Another widely used drug named bleomycin is known to cause pulmonary toxicity and cutaneous toxicity. Similarly, cyclophosphamide drug is used to treat many malignant conditions, has been reported for bladder toxicity in the 
form of alopecia, immune suppression and hemorrhagic cystitis. Meaning, modern and advanced chemotherapeutic drugs are failed to fulfil the lung cancer treatment [4-8].

Therefore, there is regular and constant demand to develop new therapeutics against cancer to meet the safety and costing strategies. Hence development of new anti-cancer therapeutics using traditional natural products and plants has attracted much attention of scientific communities in the last 3 decades $[9,10]$. At present, about $60 \%$ anticancer drugs are derived from the plants due to its affordability and lower side effects (except few plants). Plants like Vinca alkaloids, Taxus diterpenes, Podophyllum lignans and Camptotheca alkaloids have been found most effective against cancer. Moreover, flavopiridol isolates from the Indian tree Dysoxylum binectariferum and compound like meisoindigo isolated from the Chinese plant Indigo feratinctoria have been reported for their potential anti-cancer activities than conventional drugs [2-4]. Approximately more than 3000 plant varieties worldwide have been known and used to treat cancer. In Asia, about $50 \%$ people use these plants and its derived compounds to treat cancer [1]. India, bestowed with a large biodiversity. From ancient time Indians have been using plant derived compounds to treat various ailments. Indeed, plants produces different kind of phytochemicals for their protection and development in different habitats, perhaps, hence selection of a same plant from different habitat and region may give different results [11]. Therefore, in present study we selected aforesaid three ethno-medicinal plants to check their efficacy against anti-cancer activities.

\section{Materials and Methods}

\section{Plant Selection and Authentication}

The selected plants are collected from Umred forest during July to November 2018. Plant authentication was done with the help of herbariums at the department of Botany, Dr Ambedkar College, Deekshabhoomi Nagpur.

\section{Plant Extract Preparation}

Selected plants were dried in a shed and then subjected to Soxhlet apparatus and Rotary evaporator for their methanol and distilled water extracts. Suitable concentrations of the extracts were prepared using $1 \%$ Dimethyl Sulphoxide.

\section{Cell Line}

Human lung adenocarcinoma A549 cells were purchased from the National Centre for Cell Science (NCCS) Pune and maintained in Ham's F12 nutrient mixture (Himedia), with $10 \%$ Fetal Bovine Serum (FBS) (Hyclone) and 1\% streptomycin and penicilin antibiotic
(Hyclone) at $37{ }^{\circ} \mathrm{C}$ at $5 \% \mathrm{CO}_{2}$. Experiments were done on fourth passaged cells.

\section{Cell Viability Assay}

Cell viability was assessed using MTT assay. $2 \times 10^{4}$ cells were seeded in required wells of 96 well plate. Cells with media were incubated at $37^{\circ} \mathrm{C}$ in $\mathrm{CO}_{2}$ incubator (Sartorious) for 24 hours with and without plant extracts. After 24 hours, media was removed and MTT (Himedia) was added at a concentration $5 \mathrm{mg} / \mathrm{ml}$ and again incubated for 4 hours. After 4 hours MTT was removed and purple coloured farmazon crystals dissolved in 100 $\mu$ D DMSO solution. Absorbance was measured at $570 \mathrm{~nm}$ using ELISA plate reader (Bio-Rad). Results were expressed in percentage using following formula:

$$
\text { Cell Viability }=\text { OD of Sample/OD of Control } \times 100 \text {. }
$$

\section{Statistical Analysis}

Statistical analyses were done using Medcalc statistical software. Student ' $t$ ' test assuming unequal variance was used to assess the significant differences between studied groups. Data was presented in Mean \pm SEM. $\mathrm{P}<0.05$ was considered as a significant level.

\section{Results}

We found varied significant differences when selected plants with different extracts at different concentrations compared with control. For Careya arborea, we found significant decreased cell viability for $10 \mu \mathrm{g} / \mathrm{ml}(\mathrm{p}<0.0001)$ and $20 \mu \mathrm{g} / \mathrm{ml}(\mathrm{p}<0.001)$ methanol extract. However, we found non-significant difference for $40 \mu \mathrm{g} / \mathrm{ml}$ methanol extract when compared with control. However, for distilled water extract, we found significantly increased cell viability for $20 \mu \mathrm{g} / \mathrm{ml}(\mathrm{p}<0.05)$ and $40 \mu \mathrm{g} / \mathrm{ml}(\mathrm{p}<0.01)$ concentrations. A non-significant difference was found when $10 \mu \mathrm{g} / \mathrm{ml}$ extract compared with control (Table 1; Figure 1: a and b). For Ficus religiosa, we found significant increased cell viability for $10 \mu \mathrm{g} / \mathrm{ml}(\mathrm{p}<0.0001)$ and $40 \mu \mathrm{g} / \mathrm{ml}(\mathrm{p}<0.001)$ methanol extract.

However, we found non-significant difference between control and $20 \mu \mathrm{g} / \mathrm{ml}$ methanol extract. For distilled water extract, we found significant increased cell viability for 10 $\mu \mathrm{g} / \mathrm{ml}(\mathrm{p}<0.0001)$ and $20 \mu \mathrm{g} / \mathrm{ml}(\mathrm{p}<0.01)$ and $40 \mu \mathrm{g} / \mathrm{ml}$ $(\mathrm{p}<0.001)$ concentrations (Table 1; Figure 1: $\mathrm{c}$ and d).For Amorphophallus campanulatus, we found significant increased cell viability for $10 \mu \mathrm{g} / \mathrm{ml}(\mathrm{p}<0.0001)$ and 40 $\mu \mathrm{g} / \mathrm{ml}(\mathrm{p}<0.001)$ methanol extract, while a non-significant difference was found between control and $20 \mu \mathrm{g} / \mathrm{ml}$ extract. For distilled water extract, we found significant increased cell viability for $10 \mu \mathrm{g} / \mathrm{ml}(\mathrm{p}<0.001)$ and $20 \mu \mathrm{g} / \mathrm{ml}(\mathrm{p}<0.01)$ and $40 \mu \mathrm{g} / \mathrm{ml}(\mathrm{p}<0.001)$ concentrations (Table 1; Figure 1: e and $f$ ). 
Table 1. Data showing cell viability assay of selected plants with different plant extracts at different concentrations.

\begin{tabular}{|c|c|c|c|c|}
\hline \multirow[b]{2}{*}{ PLANTS } & \multirow[b]{2}{*}{ EXTRACT } & \multicolumn{3}{|c|}{ Percentage of Cell Viability at } \\
\hline & & $\begin{array}{c}10 \mu \mathrm{g} / \mathrm{ml} \\
\text { Mean } \pm \text { SEM }\end{array}$ & $\begin{array}{c}20 \mu \mathrm{g} / \mathrm{ml} \\
\text { Mean } \pm \text { SEM }\end{array}$ & $\begin{array}{c}40 \mu \mathrm{g} / \mathrm{ml} \\
\text { Mean } \pm \text { SEM }\end{array}$ \\
\hline Control & & $100.003 \pm 00$ & $100.003 \pm 00$ & $100.003 \pm 00$ \\
\hline \multirow{2}{*}{$\begin{array}{c}\text { Careya } \\
\text { arborea }\end{array}$} & Methanol & $20.18 \pm 0.41$ **** & $48.90 \pm 1.52 * * *$ & $94.01 \pm 21.98$ \\
\hline & Distilled Water & $98.13 \pm 1.66$ & $234.64 \pm 19.48 *$ & $137.96 \pm 3.53 * *$ \\
\hline \multirow{2}{*}{$\begin{array}{c}\text { Ficus } \\
\text { religiosa }\end{array}$} & Methanol & $218.33 \pm 1.13^{* * * * *}$ & $101.84 \pm 2.17$ & $331.55 \pm 0.001 * * *$ \\
\hline & Distilled Water & $193.53 \pm 1.85^{* * * * *}$ & $126.12 \pm 1.73 * *$ & $350.74 \pm 6.22 * * *$ \\
\hline \multirow{2}{*}{$\begin{array}{c}\text { Amorphophallus } \\
\text { campanulatus }\end{array}$} & Methanol & $218.33 \pm 1.13^{* * * * *}$ & $101.84 \pm 2.17$ & $331.55 \pm 7.87$ *** \\
\hline & Distilled Water & $193.53 \pm 1.85^{* * *}$ & $126.12 \pm 1.73 * *$ & $350.74 \pm 6.22 * * *$ \\
\hline
\end{tabular}

$* \mathrm{p}<0.05 ; * * \mathrm{p}<0.01 ; * * * \mathrm{p}<0.001 ; * * * * \mathrm{p}<0.0001$. SEM: Standard Error Mean. Different concentrations of plant extracts were compared with control.

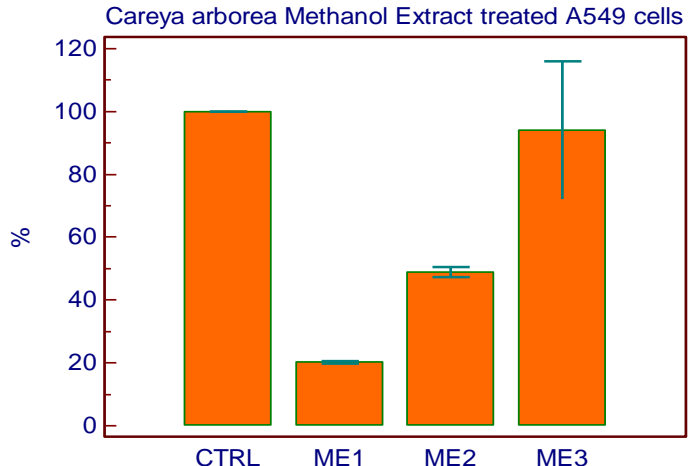

(a)

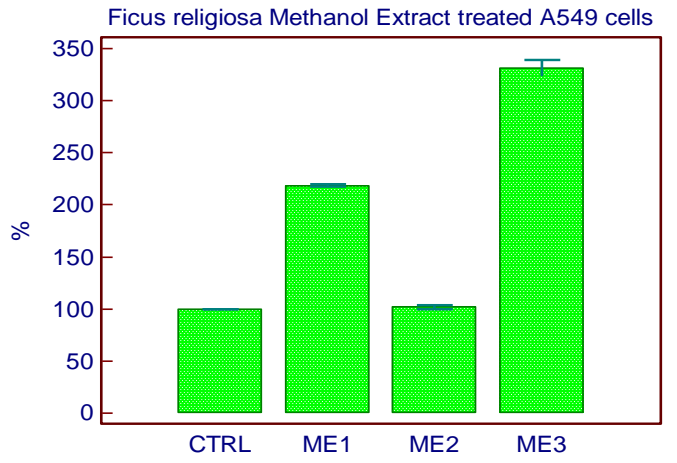

(c)

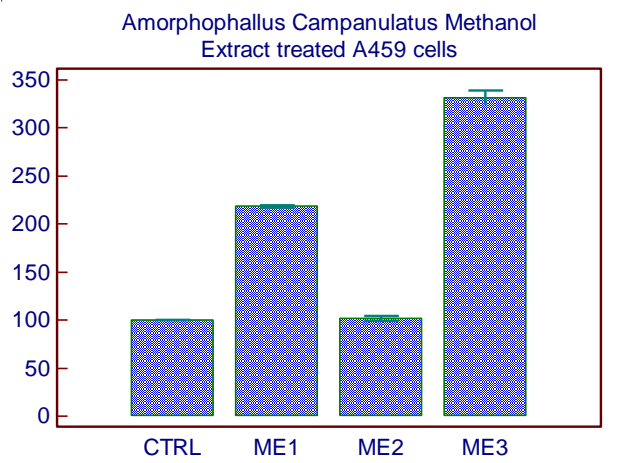

(e)

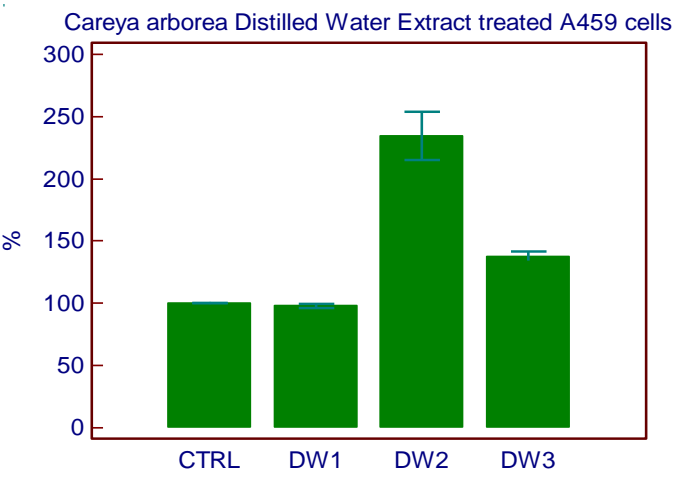

(b)

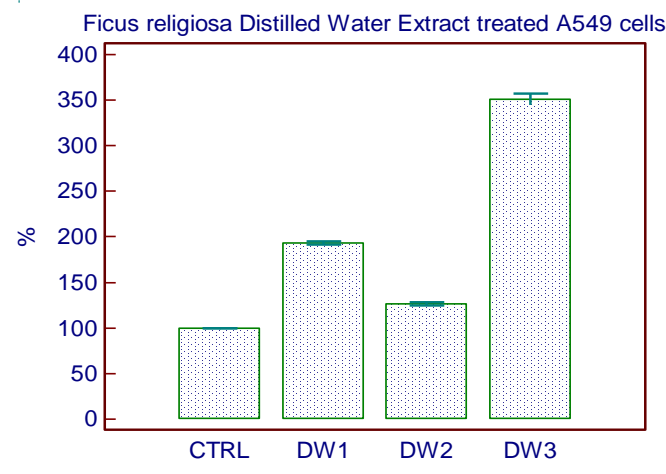

(d)

Amorphophallus Campanulatus Distilled Water Extract

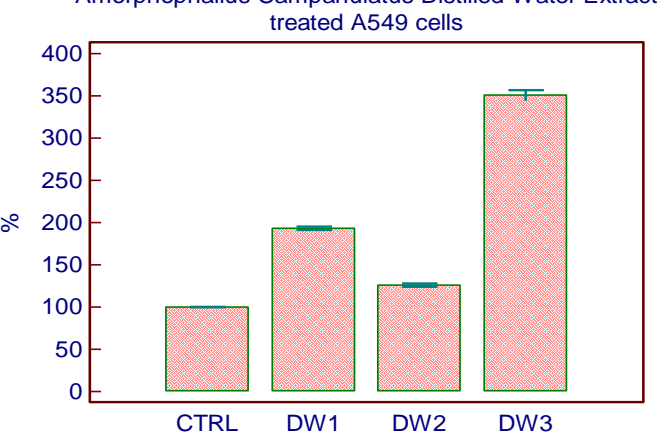

(f)

Figure 1. Figures representing cell viability percentage of A549 cells when treated with different plant extracts at different concentrations. Figure (a) and (b) representing cell viability of Careya arborea plant methanol and distilled water extract respectively. Figure (c) and (d) represents cell viability of Ficus religiosa plant methanol and distilled water extract respectively and figure (e) and (f) represents cell viability of Amorphophallus campanulatus plant methanol and distilled water extract respectively. CTRL: Control; ME1: Methanol Extract $(10 \mu \mathrm{g} / \mathrm{ml}), \mathrm{ME} 2$ : Methanol Extract $(20 \mu \mathrm{g} / \mathrm{ml}), \mathrm{ME} 3$ : Methanol Extract (40 $\mu \mathrm{g} / \mathrm{ml})$, DW1: Distilled water $(10 \mu \mathrm{g} / \mathrm{ml})$, DW2: Distilled Water (20 $\mu \mathrm{g} / \mathrm{ml})$, DW3: Distilled Water (40 $\mu \mathrm{g} / \mathrm{ml})$. 


\section{Discussion}

Screening of plants for anti-cancer activities urge to search for more reliable and potent drugs. Worldwide research is going to derive natural product-based therapeutics not only for cancer but also to treat other ailments. So, being one of the greatest and diverse biodiversity, India should lead the world. Hence through this work, we drive to focus the plants of central India for deriving such novel therapeutics. Prodigious work done on plants has already explored publications on plant-derived compounds as novel drug molecules.

Moreover, to determine active biological compounds from the plants we need to explore our traditional knowledge about plants and natural product that we have gathered since ancient time against various diseases; by providing a scientific shred of evidence. Plants have various phytochemicals which may lead to in-vitro cell survival or cell death. By isolating such bio-active compound from plants we may treat various diseases [12, 13]. Cancer is a condition where there is continuous cell growth with a lost apoptosis mechanism. This may lead to tumour formation resulting disrupt cellular mechanism and death. To suppress tumour growth numerous medications and the treatments are available, but a question is always posed for their reliability and safety [14]. Therapeutics derived from natural products may oppose this question and hence plant derived bioactive compounds have attended much importance in the field of cancer research [15]. Therefore, the present study aimed to screen three ethno-medicinal plants for anti-lung cancer activity using A549 human adenocarcinoma cells. In the present study, among all three selected ethno medicinal plants methanolic extract of Careya arborea exhibited the decreased cell viability as compared to the control. Result showed that this plant may have a property to treat human lung cancer. Methanolic extract of Careya arborea at the concentration of $10 \mathrm{ug} / \mathrm{ml}$ and $20 \mathrm{ug} / \mathrm{ml}$ exhibited the decreased cell viability, however with a concentration at $40 \mathrm{ug} / \mathrm{ml}$ showed a non- significant difference. This is possibly due to the fact that, we used a crude methanolic extract of the plant, which contains numerous useful and unusual bioactive compounds [16]. Distilled water extract of the plant showed increased cell viability, suggesting its non-potential to treat A549 cells. Methanolic and distilled water extracts of Ficus religiosa and Amorphophallus campanulatus also showed significant increased cell viability suggesting their non-anti-cancerous activities. Of note, the possible reason for the non-linear relationship between dose and effects for all studies plants could be the crude extracts. Further, the phytochemicals or plants secondary metabolites synthesised by plants may promote cell growth and differentiation. Cancer is modulated by a variety of cellular signalling pathways, albeit, to inhibit cancer via modulating such signalling pathways plant must possess special kind of biochemical compounds that can modulate such cancer leading mechanisms. Although Ficus religiosa and Amorphophallus campanulatus did not show anti-cancer activities, their phytochemicals might use for other ailments; as each plant may synthesise different phytochemicals at different climatic conditions. Thus, one can predict that Careya arborea from different geographical locations and habitat conditions may exert different results.

Worldwide research on medicinal plants suggested their complete phytochemical and biochemical analysis, required to derive their best possible biological outcomes. Tinospora cardiofolia also is known as giloya in Hindi and heartleaf plant in English is a smooth climbing shrub often abundant in India, Myanmar, China and Shri Lanka. In Ayurveda, this plant is considered to be "amrita" for its longevity, youthfulness and vitality. This plant is also well known for its anti-inflammatory, anti-arthritis and anti-allergic properties often use against general debility, dyspepsia, fever, urinary diseases and jaundice. Stem extract found to be active against various skin diseases. This plant is also reported for high anti-oxidant content and immune-modulatory activities. Methanolic extract of Tinospora cardiofola contains alkaloid like choline, isocolumbin, tinosporin, columbine, palmatine, magnoflorine and tetrahydropalmatine as active components. Dose dependant increased concentration of methanolic extract of this plant found effective against HeLa cancer cell lines. However, it's anti-cancer activity also found in rats where it reported for rapid tumour suppression ata dose of $50 \mathrm{mg} / \mathrm{Kg}$ [4, 17-24].

Another example is related to Ziziphus nummularia, also known as beri in Hindi and jujube in English, is a shrub, with purplish stem, found abundant in India, Pakistan, Afganistan, Egypt etc. Different plant parts like root, bark, stem, flowers and seeds have been reported for different biological activities. The bark and the stem of this plant found rich in two phytochemicals called betulin and betulinic acid. Both compounds exhibited anti-cancer activities. Betulinic acid has been reported to induce apoptosis in cancer cells by increasing reactive oxygen species concentration, topoisomerase inhibition, mitogen-activated protein kinase (AMP kinase) cascade activation, and angiogenesis inhibition and by modulating pro-growth transcriptional activators. Moreover, betulinic acid has been reported to induce apoptosis by p53 and CD95 independent mechanism. It has been revealed that the combined treatment of betulnilic acid and other anti-cancer drugs induces loss of mitochondrial membrane potential and releases cytochrome-c and thereby induce apoptosis [4, 25-32].

From above cited examples it has been assumed that the selected plants of this study might possess properties against not only for cancer but also for other ailments and hence, demand in detail study to elucidated their phytochemicals rather active biochemical structures, to open a new window for researchers in central India. 


\section{Conclusions}

Among selected three ethno-medicinal plants crude methanolic extract of Careya arborea might have a potential to treat human lung adenocarcinoma. Other two plants may have different types of potentials to treat varied diseases and ailments. Although this is a basic study providing first superficial inference; finding bioactive compounds using high-end techniques like high-performance liquid chromatography (HPLC) and Gas chromatography-mass spectrophotometry (GC-MS) analysis are required. Further, the bioactive guided assay may use as a track to elucidate enormous biological functions of these plants.

\section{REFERENCES}

[1] M Greenwell, P.K. Rahman. Medicinal plants: their use in anticancer treatment, International journal of pharmaceutical sciences and research, Vol. 6, No. 4103, 2015.

[2] Grever, R. Michael, A. Saul, Schepartz, and A. Bruce Chabner. The National Cancer Institute: cancer drug discovery and development program, Seminars in oncology, Vol. 19, No. 622-638, 1992.

[3] Shewach, S. Donna S, and R. D. Kuchta. Introduction to cancer chemotherapeutics, 2859-2861, 2009.

[4] Desai, G. Avni. Medicinal plants and cancer chemoprevention, Current drug metabolism Vol. 9, No. 581-591, 2008.

[5] Solowey, Elisha. Evaluating medicinal plants for anticancer activity, The Scientific World Journal, Vol. 2014, No.1-12, 2014.

[6] Kumar and Sunil. The anticancer potential of flavonoids isolated from the stem bark of Erythrina suberosa through induction of apoptosis and inhibition of STAT signalling pathway in human leukemia HL-60 cells, Chemico-biological interactions, Vol. 205, No. 128-137, 2013.

[7] L.A. Torre, R.L. Siegel, A. Jemal. Lung cancer statistics, In Lung cancer and personalized medicine Springer, Cham, 1-119, 2016.

[8] C. DeSantis, D. Naishadham, A. Jemal. Cancer statistics for African Americans, CA: a cancer journal for clinicians, Vol. 63, No. 151-66, 2003.

[9] L.A. Ries, D. Harkins, M. Krapcho, A. Mariotto, B.A. Miller, E.J. Feuer, L.X. Clegg, M.P. Eisner, M.J. Horner, N. Howlader, M Hayat. SEER cancer statistics review, 1975-2003.

[10] J. Subramanian, R. Govindan. Lung cancer in never smokers: a review, Journal of clinical oncology, Vol. 10, No. 561-70, 2007.

[11] H. Wang, O. Khor, L. Shu, Z.Y. Su, F. Fuentes, J.H. Lee, A.N. Kong. Plants vs. cancer: a review on natural phytochemicals in preventing and treating cancers and their drug ability, Anti-Cancer Agents in Medicinal Chemistry (Formerly Current Medicinal Chemistry-Anti-Cancer Agents), Vol. 12, No.1281-305, 2012.

[12] P.E. Miller, D.C. Snyder. Phytochemicals and cancer risk: a review of the epidemiological evidence, Nutrition in Clinical Practice, Vol. 27, No. 599-612, 2012.

[13] P. Talalay, J.W. Fahey. Phytochemicals from cruciferous plants protect against cancer by modulating carcinogen metabolism, The Journal of nutrition, Vol. 131, No. 3027S-33S, 2001.

[14] N.I. Weijl, M.F. Rutten, A.H. Zwinderman, H.J. Keizer, M.A. Nooy, F.R. Rosendaal, F.J. Cleton, S. Osanto. Thromboembolic events during chemotherapy for germ cell cancer: a cohort study and review of the literature, Journal of Clinical Oncology, Vol. 18, No. 2169-78, 2018.

[15] A. Montazeri, C.R. Gillis, J. McEwen. Quality of life in patients with lung cancer: a review of literature from 1970 to 1995, Chest, VoL. 113, No. 467-81, 1998.

[16] J.P. Robinson, K. Suriya, R. Subbaiya, P. Ponmurugan. Antioxidant and cytotoxic activity of Tecoma stans against lung cancer cell line (A549), Brazilian Journal of Pharmaceutical Sciences, VoL.53, No. 3, 2017.

[17] S.S. Singh, S. Srivastava, V.S. Gupta, B. Patro, A.C. Ghosh, Indian journal of Pharmacology, Vol. 35, No. 83-91, 2003.

[18] S. Diwanay, D. Chitre, B. J. Patwardhan. Immunoprotection by botanical drugs in cancer chemotherapy, Journal of Ethnopharmacol, Vol. 90, No. 49-55, 2004.

[19] K.M. Nadkarni, A.K. Nadkarni. Indian Materia medica, Popular Prakashan Pvt. Ltd, India, 1976.

[20] T.F. Zhao, X.K. Wang, A.M. Rimando, C.T. Che. Folkloric medicinal plants: Tinospora sagittata var. cravaniana and Mahonia bealei Planta, Planta Medica, Vol. 57, No. 505, 1991.

[21] G.C. Jagetia, V. Nayak, M.S. Vidyasagar. Evaluation of the antineoplastic activity of guduchi (Tinospora cordifolia) in cultured HeLa cells, Cancer Letters, Vol. 127, No. 71-82, 1998.

[22] J. Sarek, M. Kvasnica, M. Urban, J. Klinot, M. H. Bioorg. Correlation of cytotoxic activity of betulinines and their hydroxy analogues, Bioorganic and medicinal chemistry letters, Vol. 15, No. 4196-4200, 2005.

[23] Gauthier C, Legault J, Lebrun M, Dufour P, Pichette A. Bioorg. Glycosidation of lupane-type triterpenoids as potent in vitro cytotoxic agents, Medicinal Chemistry, Vol. 14, No. 6713-6725, 2006.

[24] D. A. Eiznhamer, Z.Q. Xu. Betulinic acid: a promising anticancer candidate, Drugs, Vol. 7, No. 359-373, 2004.

[25] F. Simone. Sensitization for anticancer drug-induced apoptosis by betulinic Acid, Neoplasia, Vol. 7, No.162-170, 2007.

[26] Puri, Anju. Immunostimulant agents from Andrographis paniculata, Journal of Natural Products, Vol. 56, No. 995-999, 1993.

[27] S.R. Jada, G.S. Subur, C. Matthews, A.S. Hamzah, N.H. 
Lajis, M.S. Saad, M. F. Stevens, Stanslas. Semisynthesis and in vitro anticancer activities of andrographolide analogues, Journal of Phytochemistry, Vol. 68, No. 904-912, 2007.

[28] T. Matsuda, M. Kuroyanagi, S. Sugiyama, K. Umehara, A. Ueno, K. Nishi. Cell differentiation-inducing diterpenes from Andrographis paniculata Nees, Chemical and Pharmaceutical Bulletin, Vol. 42, No. 1216-1225, 1994.

[29] R. P. Singh, S. Bannerjee, A. Rao. Modulatory influence of Andrographis paniculata on mouse hepatic and extrahepatic carcinogen metabolizing enzymes and antioxidant status, Phytotherapy Research, Vol. 15, No. 382-390, 2001.

[30] T.D. Babu, G. Kuttan, J.J. Padikkala. Cytotoxic and anti-tumour properties of certain taxa of Umbelliferae with special reference to Centella asiatica (L.) Urban, Journal of ethnopharmacology, Vol. 48, No. 53-57, 1995.

[31] J. Sharma J, R. Sharma. Radioprotection of Swiss albino mouse by Centella asiatica extract." Phytotherapy Research: An International Journal Devoted to Pharmacological and Toxicological Evaluation of Natural Product Derivatives, Vol. 16, No. 785-786, 2002.

[32] D. Chandraprabha, S. Annapurani, and N. K. Murthy. Testing the mutagenicity/comutageneticity/antimutagenicity of selected medicinal plants by the oxidative mutant strain Salmonella typhimurium TA 102, Indian Journal of Nutrition Diet, Vol. 33, No. 74-79, 1996. 